Policy, Planning, and Research

\title{
WORKING ·PAPERS
}

Office of the Vice President

Development Economics

The World Bank

September 1989

WPS 280

\section{Adjustment Policies in East Asia}

\section{Bela Balassa}

Policy differences explain why East Asia's newly industrializing economies outperformed Latin America's in per capita income. But it is inappropriate for Korea and Taiwan to run current account surpluses when they can get higher returns from domestic investment than from foreign securities or gold. 


\section{WORKING PAPERS}

Office of the Vice Preslcient

Having passed through the first stage of import substitution, which involved the replacement of the imports of nondurable consumer goods and their inputs by domestic production, two East Asian newly industrialized economies - Korea and Taiwan - embarked on an outward oriented development strategy that gave a boost to manufactured exports and economic growth. This contrasts with the policies applied by three Latin American newly industrializing countries, Argentina, Brazil, and Mexico, which passed to the second stage of import substitution that concemed consumer and producer durables and intermediate products and reformed their policies only after the adverse effects of these policies became apparent.

The two East Asian economies continued with outward-oriented policies during the period of the two oil crises and limitcd reliance on external borrowing. In turn, the three Latin American economies again tumed inward and placed considerable reliance on foreign loans. These policy differences by and large continued after the debt crisis, except that the three Latin American economies had to apply deflationary measures in view of the unavailability of external capital.

Differences in the policies applied explain the different economic performance of the East Asian and the Latin American economies, with the former much surpassing the latter in per capita incomes. At the same time, it is inappropriate for Korea and Taiwan to run current account surpluses when they can obtain higher returns on domestically invested capital than on capital invested in foreign securities and gold.

This paper is a product of the Office of the Vice President, Development Economics. Copies are available free from the World Bank, $1818 \mathrm{H}$ Street NW, Washington DC 20433. Please contact Norma Campbell, room S9-047, extension 33769 (26 pages with tables). 
ADJUSTMENT POLICIES IN EAST ASIA

\author{
Bela Balassa *
}

Table of Contents

Page No.

I. Economic Policies, 1963-1973 .............. 1

II. Policy Responses to External Shocks, 1974-1981 . . . . . 5

III. Policies in the Period Following the Debt Crisis, 1982-1988 10

IV. Current Account urpluses and Policies for the Future . . 11

v. Conclusions...................... 18

* The author is Professor of Political Economy at the Johns Hopkins University and Consultant to the World Bank. He presented this paper at the December 1988 meetings of the American Economic Association. The author is indebted to Shigeru Aki yama for research assistance. 


\section{ADJUSTMENT POLICIES IN EAST ASIA}

Bela Balassa

This paper will examine the adjustment policies applied by two East Asian newly-industrializing economies, Korea and Taiwan (China), in the period following the quadrupling of oil prices in 1973. As an introduction to the discussion, the policy performance of the two East Asian economies prior to 1973 will be analyzed, comparing their performance to that of three Latin American newly-industrıalizing econowies, Argentina, Brazil, and Mexico. This will be followed by an examination of adjustment policies in the periods of the first and the second oil shocks and a discussion of the policies applied in the subsequent period, when shifts from current account deficits to current account surpluses occurred in the two East Asian economies. Finally, desirable policies for the future will be considered.

I. Economic Policies, 1963-1973

Apart from the city state of Hong Kong, all developing countries protected their incipient manufacturing industries producing nondurable consumer goods and tneir inputs. This is customarily called the "easy" stage of import substitution as developing countries possess certain advantages in the production of the commodities in question. Nondurable consumer goods, such as clothing, shoes, and furniture, and their inputs, such as textile fabrics, leather, and wood, are relatively labor intensive; the efficient scale of output is low, and costs do nct rise substantially at lower output levels; production does not involve the use of sophisticated technology; and a network of suppliers of parts, components, and accessories is not required for efficient operatious. 
In the course of first-stage import substitution, domestic production will rise more rapidly than domestic consumption, since it not only provides for increases in consumption but also replaces imports. Once the process of import substitution in nondurable consumer goods and their inputs has been completed, however, the growth rate of output will decline to that of domestic consumption. Developing economies that wish to maintain high rates of industrial growth, ther, face a choice between turning to the exportation of manufactured goods or embarking on the second stage of import substitution.

In Korea and Taiwan, the choice was made for outward-oriented development policies that gave a boost to the exports of manufactured goods. The policies applied involved providing similar incentives to sales in domestic and in export markets, thereby avoiding a bias against exports.

In both Korea and Taiwan, a free-trade regime was applied to exports. Exporters were free to choose between domestic and imported inputs; they were exempted from indirect taxes on their output and inputs; and they paid no duty on imported inputs. The same privileges were extended to the producers of domestic inputs used in export production.

The application of these rules provided equal treatment to all exports. And while some additional export incentives were granted, they did not introduce much differentiation among individual export commodities. At the same time, these incentives offset, on the average, import protection in the manufacturing sector, thus ensuring that exports and import substitution received similar incentives. Furthermore, there was little discrimination against primary exports and primary activities in general.

In turn, the three Latin American newly-industrializing economies, Argentina, Brazil, and Mexico, moved to the second stage of import 
substitution after the completion of its first, easy, stage. Second stage import substitution involves the replacement of imports of intermediate goods and producer and consumer durables by domestic production.

Intermediate goods, such as petrochemicals and steel, tend to be highly capital-intensive. They are also subject to important economies of scale and costs rise rapidly at lower output levels. Moreover, the margin of processing is relatively small, and organizational and technical inefficiences may contribute to high processing costs.

Producer durables, such as machinery, and consumer durables, such as automobiles, are also subject to economies of scale. But in these industries economies of scale relate not so much to plant size as to horizontal and vertical specialization, entailing reductions in product variety in particular plants and the manufacture of parts, components, and accessories on an efficient scale in separate plants.

At the same time, the production of parts, components, and accessories has to be done to precision for consumer durables and, especially, for machinery. This, in turn, requires the availability of skilled and technical labor and, to a greater or lesser extent, the application of sophisticated technology. There is also need for a network of suppliers of parts, components, and accessories for efficient operations.

Given the relative scarcity of physical and human capital in developing countries that have completed the first stage of import substitution, they are at a disadvantage in the manufacture of highly physical capital-intensive intermediate goods and skil1-intensive producer and consumer durables. By limiting the scope of exploitation of economies of scale, the relatively small size of their national markets further contributes to high 
domestic costs in these countries. Correspondingly, the establishment of these industries requires high protection.

The resulting discrimination in favor of import substitution and against exports did not permit the development of manufactured exports in countries engaging in second-stage import substitution. There were also adverse developments in primary exports that suffered the effects of high rates of industrial protection both through higher input costs and the appreciation of the exchange rate.

Import substitution did not compensate for poor export performance as the need for industrial materials and machinery limited net import savings. Correspondingly, countries engaged in second-stage import substitution suffered foreign exchange shortages, which adversely affected their economic growth. The decline in investment efficiency in highly protected industries had similar effects. The resulting deterioration in growth performance led to reforms in the incentive system of the three Latin American newly industrializing economies in the mid-1960s.

The reforms involved granting export subsidies to nontraditional exports. Exporters were not given, however, a free choice between domestic and imported inputs. Rather, in order to safeguard existing industries, exporters were required to use domestic inputs produced under high protection, for which export subsidies provided only partial compensation. Correspondingly, there continued to be a bias in favor of import substitution and against exports, albeit at a reduced rate. The extent of discrimination was especially pronounced against traditional primary exports, which did not receive export subsidies and, in some instances, continued to be subject to export taxes. 
Differences in the policies applied in the East Asian and Latin American newly-industrializing economies are apparent in their export and growth performance. As shown in Table 1, manclactured exports grew rapidly between 1963 and 1973 in Korea and Tai wan while smaller increases are shown in the three Latin American countries (In interpreting the figures, it should be noted that the Taiwanese results for 1963 were influenced by the reforms introduced in 1960 whereas Korea's reform iates from 1964).

The important role exports played in the growth process in the East Asian newly-industrializing economies is indicated by the substantial rise in their export-GDP ratios between 1963 and 1973 (Table 2). By contrast, this ratio declined in Argentina and Mexico. And while the ratio increased in Brazil, where export subsidies were higher than in the other two Latin American NICs and extended also to nontraditional primary exports, the increases were much smaller than in East Asia.

Correspondingly, considerable differences are shown in the growth performance of the East Asian and Latin American newly-industrializing economies (Table 3). Thus, per capita incomes doubled in Korea and Taiwan between 1963 and 1973 (Table 4). As a result, Taiwan surpassed Brazil in terms of per capita incomes, and both East Asian newly-industrializing economies considerably reduced the economic distance vis-a-vis Argentina and Mexico.

\section{Policy Responses to External Shocks, 1974-1981}

It was suggested that while outward orientation gave superior results than inward orientation under favorable world economic conditions prior to 1973, the two oil crises and the ensuing recessions bore heavily on outwardoriented economies. This is because outward oriented economies had much 
higher export and import ratios than inward oriented economies and the adverse effects of unfavorable world economic conditions were propagated through international trade.

In the following, this proposition will be subjected to scrutiny. This will be done by examiring the balance-of-payments effects of external shocks and policy responses to these shocks. Estimates have been made for the 1974-78 and 1978-81 periods, utilizing the framework that is described in Balassa, 1981 .

External shocks have been defined to include terms of trade effects, resulting largely from incceases in oil prices, and export volume effects, associated with the slowdown of world trade in the ensuing recessions. In the second period, there were also interest rate effects, due to increases in interest rates in world financial markets.

Policy responses to external shocks took the form of additional net external financing, represented by increased borrowing compared with past trends; export promotion, reflected by increases in export market shares; import substitution, expressed by decreases in the income elasticity of import demand; and deflationary macroeconomic policies, entailing a decline in the growth of demand for imports.

The adverse balance-of-payments effects of external shocks were indeed much larger for the East Asian, than for the Latin American, newlyindusirializing economies. As shown in Table 5, these effects equaled 10.5 percent of GDP in Korea and 7.2 percent in Taiwan, compared with 0.5 percent in Argentina, 3.3 percent for Brazil, and 1.2 percent in Mexico in the 1974-78 period. The low figures for Argentina reflect the fact that it does not 
import petroleum; also, Mexico's petroleum imports were reduced by newly discovered oil.

In view of the small balance-of-payments effects of eiternal shocks, limited interest attaches to policy responses to these shocks in Argentina. Thus, the following discussion will compare adjustment pelicies in Korea and Taiwan with those in Brazil and Mexico. In so doing, the time pattern of policy responses will also be considered. 1 '

The initial response of Korea and Taiwan to external shocks wals to adopt deflationary policies so as to avoid excessive indebtedness. In fact, both East Asian economies reduced their reliance on foreign capital as indicated by negative net additional external financing reported in Table 5. At the same time, they maintained their outward-oriented stance. Moreover, both economies devalued their exchange rate so as to promote exports and import substitution.

Combining export promotion snd import substitution in Table 5 under the heading "output-increasing policies" shows the success of the measures applied that more than offset the adverse balance-of-payments effects of external shocks. Korea's output performance was particularly favorable, turning the deflationary policies applied in the years immediately following the oil crisis into expansionary policies.

Output-increasing policies were also positive in Brazil, although to a much lesser extent than in Korea and Taiwan. At the same time, Brazil accelerated its borrowing abroad and the ratio of export promotion to import substitution was lower than in the two East Asian newly-industrializing

1/ Annual estimates are shown in Balassa, 1981. 
economies. Correspondingly, its external debt-export and debt service-export ratios increased to a considerable extent while declines or modest increases were shown in Korea and Taiwan (Table 6).

External debt-export and debt service-export ratios increased even more in Mexico, where net additional external financing exceeded the balanceof-payments effects of external shocks. At the same time, Mexico lost expori market shares and experienced less import substitution than the other newlyindustrializing economies under consideration.

These results reflect the increased emphasis on import substitution in the Latin American newly-indistrializing economies that was not the case in East Asia. In fact, Korea and Taiwan liberalized their trade during the period under consideration and the observed import substitution was the result of the exchange rate policy applies. It may be added, however, that Brazil continued with the subsidization of exports after 1973.

In the 1978-81 period, the East Asian newly industrializing economies again suffered much larger external shocks than the Latin American economies. The ratio of the adverse balance-of-payments effects of external shocks to GNP was 9.4 percent in Korea, 13.1 percent in Taiwan, 1.2 percent in Argentina, and 2.5 percent in Brazil. At the same time, Mexico benefited from external shocks through increases in oil prices on its newly found reserves that permitted substantial exports.

Taiwan continued to reduce reliance on foreign capital while maintaining its output-increasing policies that more than offset the adverse balance-of-payments effects of external shocks. This was not the case in Rorea that failed to devalue its currency for several years despite rapid 
domestic inflation. At the same tirie, Korea applied deflationary policies, thereby limiting reliance on for ign capital (Balas8a, 1985).

In Latin America, Argentina and Mexico greatly increased their reliauce on external capital during the 1978-81 period. This was not the case in Brazil, leading to a reduction in its external debt-export ratio. This ratio rose substantiall; in Argentina while declining in Mexico whose oil exports grew very rapidly.

Argentina lost export market shares and experienced negative import substitution during the period under consideration as it failed to devalue to compensate for domestic inflation. The same outcome was observed in Mexico, excluding oil exports that show up as a gain in export market shares. Finally, Brazil with its flexible exchange rate policy had modest gains in export market shares and import substitution.

Combining the 1974-78 and 1978-81 periods, we find that Korea and Taiwan benefited from continued outward orientation and, except for Korea in the latter period, from a flexible exchange rate policy. These policies led to increases in the ratio of exports to GNP while declines were experienced in Argencina and Brazil and, excluding oil, in Mexico (Table 2). And, per capita exports of manufactured goods also increased to a greater extent in the East Asian, than in the Latin American, newly-industrializing economies (Table 1 ). The adjustment policies applied permitted Korea and Taiwan to reach rapid rates of economic growth, exceeding the growth rates in Brazil and Mexico and, in particular, Argentina by a considerable margin (Table 3 ). Correspondingly, Korea also surpassed Brazil in terms of per capita incomes and income differences of the two East Asiar economies vis-a-vis Argentina and Mexico declined (Table 4). 
Thus, despite the substantial external shocks they suffered, Korea and Taiwan showed superior economic performance compared with the Latin American newly-industrializing economies. While external shocks were larger under outward orientation, the continuation of this policy permitted Korea and Taiwan to more than compensate for the adverse effects of external shocks, reaching higher economic growth rates in the process.

III. Policies in the Period Following the Debt Crisis, 1982-1988

Rapid increases in exports, together with limited reliance on foreign capital, permitted Korea and, in particular, Taiwan, to maintain low external debt-export ratios in the 1973-81 period. And while their debt service-export ratios rose, this is explained by increases in world interest rates. External debt-export ratios were considerably higher in the Latin American newlyindustrializing economies, ranging between 249 (Argentina) and 278 (Brazil), compared with 109 in Korea and 24 in Taiwan at the end of the period (Table 6).

In the following six years, external debt-export ratios increased further in the Latin American newly-industrializing economies while declining in Korea and Taiwan. These results largely reflect the fact that the Latin American NICs experienced little change in manufactured exports per head and a fall in their export-GDP ratio. Both of these ratios increased in Korea and Taiwan (Tables 1 and 2).

With slow export growth and the application of deflationary policies in response to the debt crisis, per capita incomes declined in Argentina and Mexico between 1981 and 1987 and increased only slightly in Brazil. By contrast, per capita incomes rose to a substantial extant in Korea and Taiwan. Thus, while the two East Asian economies had lower per capita incomes 
than the Latin American NICs in 1963, the situation was reversed by 1987 (Table 4).

Limiting attention to the two East Asian economies, we observe an important change in their resource flow patterns. Following earlier deficits, from 1981 onwards Taiwan and from 1985 onwards Korea had a current account surplus, i.e. they experienced an outflow rather than an inflow of savings. In the case of Taiwan, this was accompanied by increases in the domestic saving ratio and declines in the investment ratio. In Korea, it occurred as the domestic saving ratio increased, with little change in the domestic investment ratio (Table 7 ).

By 1987 , the current account surplus reached $\$ 9.9$ bilition, 8.5 percent of the gross domestic product, in Korea. Preliminary estimates indicate that the surplus may attain $\$ 14$ billion in 1988 . In turn, Taiwan's current account surplus was $\$ 18.1$ billion, 19.2 percent of GDP, in 1987. The Taiwanese surplus declined in 1988 but estimates are not yet available.

The remainder of this paper will consider the question if a continued outflow of savings is desirable in the case of Korea and Taiwan. Furthermore, policy recommendations will be made for the future.

IV. Current Account Surpluses and Policies for the Future

Is it desirable for developing economies, such as Korea and Taiwan, to run current account surpluses? To answer this question, the first issue concerns the rates of return that are obtainable in foreign and in domestic investment.

Korea holds its foreign assets largely in the form of U.S. securities, in most part short-term. Taiwan's holdings are approximately nine-tenths in U.S. securities and one-tenth in gold. U.S. short-term 
securities earn 8-9 percent a year or 4 percent adjusted for U.S. inflation. There are no earnings on gold while its price may fluctuate over time.

Fry (1988) estinated two measures of the rate of return to capital in Taiwan. These are the net productivity of capital, defined as income to capital divided by the capital stock, and the private after-tax rate of return on private capital. For 1987, the former was estimated at 18.0 percent and the latter at 18.6 percent.

Comparable estimates for Korea are not available. However, judging from the fact that incremental capital-output ratios in the two ec nomies differ little (for the 1981-86 period, these are estimated at 3.7 for Rorea and 3.4 for Taiwan), and they are of similar levels of technological development, one cannot expect large differences in rates of return to capital.

It appears, then, that Korea and Taiwan suffer substantial economic losses by investing abroad rather than domestically. With the current account surplus equal to about 11 percent of Korea's GDP and 18 percent of Taiwan's GDP and a rate of return differential of 14 perrent for Treasury securities and 18 percent for gold, these losses can be estimated at 1.5 percent and 2.6 percent of GDP, respectively.

Nor do Korea and Taiwan need to accumulate reserves for emergencies. Rorea had foreign exchange reserves and gold of $\$ 15.9$ billion in June 1989 and Taiwan $\$ 81.3$ billion in April 1989, amounting to 4 and 20 months of imports, respectively. This compares to 3 months of imports that are customarily regarded as adequate reserves.

At the same time, Taiwan has a neglible foreign external debt while Rorea's debt may amount to $\$ 26$ billion at the end of 1988 . The repayment of 
this debt with interest charges of about 11 percent (6-7 percent in real terms) cannot be considered desirable, since the rate of return on domestic investment much exceeds the interest rate on the debt. At the same time, as we have seen, the ratio of the external debt to exports has been declining over time and will fall further with rising exports in the future.

We have considered so far the choice between domestic and foreign investment. Further questions arise as to the choice between domestic consumption and the flow of domestic savings abroad. In view of the expected rapid increases in incomes as new investment embodies modern technology, it will not be appropriate to limit the growth of domestic consumption by measures that favor the outflow of capital.

Among possible distorting measures affecting the current account. balance, the exchange rate needs first to be considered. The nominal exchange rate and the real effective (trade-weighted) exchange rate, derived by adjusting the ratio of nominal exchange rate for changes in relative prices at home and abroad has been calculated for Korea, Taiwan, Japan, and the United States. The base period is 1980-82; the data extend until the first quarter of 1989 .

During this period, the Korean won depreciated by 0.6 percent vis-avis the U.S. dollar while the New Taiwan $\$$ appreciated by 25.9 percent and the Japanese yen by 44.7 percent against the U.S. currency. In turn, the real effective ezchange rate depreciated by 11.9 percent in Korea, 0.2 percent in Taiwan, and 10.5 percent in the United States, whereas an appreciation of 27.1 percent is shown for Japan.

It appears, then, that changes in real effective exchange rates vary to a considerable extent among the three economies that accumulated large 
current account surpluses (including Japan). Thus, the data provide prima facie evidence on the need for an appreciation of the exchange rate in Taiwan and in Korea.

Another way to approach the issue is to consider changes in equilibrium real effective exchange rates. As first suggested by Balassa (1964), the equilibrium real exchange rate will change as a result of differences in productivity growth between the traded and the nontraded goods sectors. While traded goods prices are equalized internationally, this is not the case for the prices of nontraded goods. Rather, the larger are differences in productivity growth between traded and nontraded goods sectors, the more will the prices of nontraded goods rise as domestic wages increase. As a result, the equilibrium real effective exchange rate will appreciate in countries with rapid increases of productivity in traded vs. nontraded goods sectors as against countries with lower rates of relative productiviry increases in the traded goods sectors.

Hsieh (1982) provided confirmation of this view for Germany and Japan, and Marston (1986) for the United States and Japan. Comparable estimates could not be made in the present case, owing to the lack of information on sectoral productivity changes. Nevertheless, some conclusions can be derived from data on overall productivity changes between 1980-82 and 1988.

We have estimated that labor productivity on the national economy level increased by 54.8 percent in Korea, 42.0 percent in Taiwan, 23.4 percent 
in Japan, a.xd 8.3 percent in the United States during this period. $1 /$

Following Balassa (1964), we assume that intercountry differences of productivity growth in nontraded goods sectors are smaller than productivity differences in traded good sectors. It would appear, then, that the productivity gap between traded and nontraded goods sectors was the largest in Korea, followed by Taiwan, Japan, and the United States.

Data on productivity growth, then, confirm the conclusion that the equilibrium real effective exchange rate appreciated to a considerable extent in Korea and Taiwan. Since the actual exchange rate did not follow suit, there is need for a substantial appreciation in the currencies of the two economies.

The need for an appreciation is mitigated, however, to the extent that Korea and Taiwan reduce their import protection. This is also in the interest of the two economies since protection interferes with the efficiency of resource allocation.

It has been reported that, following the trade liberalization measures undertaken in recent years, approximately 5 percent of Korean and Taiwanese imports remain subject to quantitative import restrictions. Such figures are misleading, however, since products which are imported in small quantities are given small weight and products which are not imported do not appear in the calculation at all.

In this connection, reference may be made to the share of the imports of motor vehicles (SITC category 78) and of miscellaneous manufactured goods, mainly consumer goods (SITC class 8) in total imports. In 1987, motor vehicle

1/ IMF, International Financial statistics and national data. 
imports accounted for 17.6 percent of total imports in the United State $8,8.8$ percent in France, 7.0 percent in Germany, and 9.4 percent in the United Kingdom; the corresponding ratios were only 2.0 percent in Korea and 3.6 percent in Taiwan. In turn, the share of miscellaneous manufactured goods in total imports were 16.1 percent in the United States, 13.8 percent in France, 15.0 percent in Germany, 13.7 percent in the United Kingdom, 5.3 percent in Korea, and 4.1 percent in Taiwan. $1 /$

It appears, then, that there are considerable possibilities for increasing the imports of motor vehicles and miscellaneous manufactured goods in both Korea and Taiwan. Further possibilities exist in agriculture where import prohibitions and limited import quotas have been used in the two economies. Finally, the imports of services, such as insurance, motion pictures, and telecommunications, should be liberalized.

In order to limit the extent of the appreciation of their currencies, which also disfavor exports, and to improve the efficiency of resource allocation, it would be desirable for Korea and Taiwan to abolish all quantitative import restrictions. This could be done speedily for manufactured goods while it could be implemented over time for agricultural products.

The same objectives would be served by lowering tariffs. Much has been done in this regard in both Korea and Taiwan in recent years but tariffs remain high for automobiles and various foodstusfs. An appropriate objective would be to lower tariffs to rates observed in the industrial countries, to an average of about 5 percent. At the same time, the dispersion of tariff rates 
about this average should be reduced.

Lowering import protection will permit Korea and Taiwan to forego the use of export incentives which are now employed to avoid an anti-export bias in the incentive system. This will, then, represent a further step towards a free trade situation.

The question arises how will the proposed measures, including an appreciation of the exchange rate, lowering import protection, and reducing export incentives, affect the savings-investment balance. These measures operate in part through reductions in savings that result as profits in traded goods industries and rents in agriculture decline, $1 /$ and in part through increases in investment as resource reallocation according to comparative advantage leads to higher investment.

Another source of distortions in Korea and Taiwan is the restrictions imposed on the financial system. These restrictions interfere with investment activity as they do not ensure that all profitable investment projects are financed. The liberalization of the financial system, then, would contribute to increased investment.

A variety of measures may be taken to liberalize the financial system in Korea and Taiwan. They include freeing interest rates; reducing government intervention in the operation of banks and, in the case of Taiwan, privatizing state-owned banks; allowing for the entry of new banks and for increases in the number of branches of existing banks; and admitting an increased number of foreign banks. These measures would need to be accompanied by increasing the supervision of the banking system so as to avoid irregularities.

If On this point, see also Balassa and Williamson, 1987, p. 27. 
There would further be need to liberalize money markets and to develop capital markets. This would require enlarging the scope of available monetary instruments and increasing the number of firms that operate in money and capital markets. At the same time, existing regulations on the operation of these markets should be strengthened.

Apart from reducing existing distortions, investment in Korea and Taiwan could be increased directly by improvements in infrastructure. In this connection, it may be noted that the 14 major infrastructure projects in Taiwan are behind schedule. In Korea, too, there are unmet infrastructural needs, in particular in roads, where public investment could contribute to private \&nvestment.

Finally, the effects of the appreciation of the currency would be enhanced by expansionary measures. Nor should one fear the inflationary effects of such measures since the appreciation of the currency will have deflationary conseouences.

\section{Conclusions}

This paper has examined the adjustment policies followed in two East Asian newly-industrializing economies: Korea and Taiwan. As an introduction to the discussion, the economic policies applied by these two economies in the 1963-73 period were reviewed. In so doing, comparisons were made with three Latin American newly-industrializing economies: Argentina, Brazil, and Mexico.

It has been shown that while the East Asian NICs adopted outwardoriented policies, providing similar incentives to exports and import substitution, the Latin American NICs applied inward-oriented policies, with subsequent reforms reducing but not eliminating the bias of the incentive 
system against exports. The effects of differences in policies are apparent in economic performance as the East Asian NICs reached much higher export and GWP growth rates than the Latin American NICs.

While the outward oriented East Asian NICs suffered considerably larger external shocks than the Latin American NICs in the 1973-78 period, they succeeded in overcoming these shocks and attained higher economic growth rates than the latter group of national economies. The policies applied involved adopting deflationary measures initially so as to avoid excessive indebtedness as well as continued outward orientation, with reliance placed on the exchange rate to pursue output-increasing policies of export promotion and import substitution.

Responses to the second oil shock were similar. Correspondingly, export-GNP ratios increased in the East Asian NICs while declining in the Lat in American NICs. Also, economic growth rates were considerably higher in the former than in the latter group. At the same time, external debt ratios remained low in Korea and Taiwan but rose to a considerable extent in Argentina, Brazil, and Mexico.

With the onslaught of the debt crisis, Latin American economies had to apply deflationary measures and experienced slow export growth, resulting in poor economic performance. By contrast, exports and per capita incomes rose rapidly in Korea and Taiwan. Also, the two East Asian economies shifted from an inflow to an outflow of savings.

The paper raises the question if it is desirable for developing economies, such as Korea and Taiwan, to run a current account surplus. It answers this question in the negative, noting that both economies can obtain much higher returns on domestically invested capital than on capital invested 
abroad and, in view of expected rapid increases in incomes, it is not appropriate to limit the growth of domestic consumption.

The paper suggests remedying the policy distortions that tend to contribute to the outflow of capital. Recommendations have been made for the appreciation of the exchange rate, reductions in import protection, and the elimination of export incentives. It has further been proposed to liberalize financial markets.

At the same time, investments in Korea and Taiwan could be increased by improvements in infrastructure. Finally, the appreciation of the exchange rate would need to be accompanied by expansionary policies that would contribute to increased consumption. 


\section{REFERENCES}

Balassa, Bela, "The Purchasing Power Parity Doctrine: A Reappraisal," Journal of Political Economy 72(6), December 1964, Pp. 1258-67.

Balassa, Bela, "The Newly-Industrializing Developing Countries After the Oil Crisis," Weltwirtschaftliches Archiv, Band 117, Heft 1, 1981, Pp. 14294. Reprinted as Essay 2 in Bela Balassa, The Newly Industrializing Countries in the World Economy, New York, Pergamon Press, 1981, Pp. 29-81.

Balassa, Bela, "Adjusting to External Shocks: The Newly-Industrializing Developing Economies in 1974-76 and 1979-81," Weltwirtschaftliches Archiv Band 121, Heft 1, 1985, Pp. 116-41.

Balassa, Bela and John Williamson, Adjusting to Success: Balance of Payments Policy in the East Asian NICs, Policy Analyses in International Economics, Wo. 17, Washington, D.C., Institute for International Economies, June 1987.

Fry, Maxwell J., "Should Taiwan Reduce Its Current Account Surplus?" University of California, Irvine, November 1988 (mimeo).

Hsieh, David A, "The Determination of the Real Exchange Rate: The Productivity Approach," Journal of International Economics, 12(3/4), May 1987, Pp. 355-62.

Marston, Richard C., "Real Exchange Rates and Productivity Growth in the United States and Japan," National Bureau of Economic Research Working Paper No. 1922, May 1986. 
Table 1

Per Capita Exports of Manufactured Goods in Selected Newly-Industrializing Economies (US\$)

1963

1973

1981

1987

Korea

Taiwan

Argentina

Brazil

Mexico

$\begin{array}{rr}1 & 79 \\ 11 & 238 \\ 4 & 29 \\ 1 & 12 \\ 4 & 20\end{array}$

493

1035

2395

1111

63

73

78

Sources: United Nations, COMTRADE data base; World Bank data base. Note: * 1986.

Table 2

Export-GDP Ratios in Selected ilewly-Industriaiizing Economies (percent) 1963

1973

1981

1987

Korea

Taiwan

2.3

24.2

30.8

42.1

15.3

10.1

8.4

47.6

7.3

12.8

Brazil

5.7

4.1

8.5

6.2

8.1

35.9

49.9

$2.3^{*}$

3.8

Mexico

.24 .1

$5.6^{*}$

Sources: United Nations, COMTRADE data base; World Bank data base. Note: * 1986 
Table 3

GDP Growth Rates in Selected Newly-Industrializing Bconomies (percent)

1963-73

1973-81

1981-87

1963-87

Korea

Taiwan

Argentina

Irazil

Mexico
9.3

11.1

5.0

8.2

7.4
7.8

8.0

1.2

5.7

6.6
8.9

7.6

0.9

3.8

$-1.0$
8.7

9.2

2.7

6.3

5.2

Source: World Bank data base.

Table 4

Per Capita Incomes in Selected Newly-Industrializing Economies

(U.S. dollars)

At Purchasing Power Parities

(1975 prices)

At Exchange Rates

(1987 prices)

$$
1963
$$

1973

1981

1987

1987

Korea

690

1356

2122

3252

$826 \quad 1691 \quad 2631 \quad 3755$

Taiwan

2036

3045

2944

2834

Brazil

983

1624

2034

2235

$\begin{array}{llll}1499 & 2170 & 2680 & 2338\end{array}$

2883

4804

1503

Sources: 1963 and 1973: R. Summers and A. Heston, "Improved International Comparisons of Real Product and Its Composition" Review of Income and Wealth 30:2 June 1984), pp. 207-60; 1981 nd 1987: World Bank data base.

Note: * 1986 


\section{Table 5}

Bal ance-of-Payments Effects of External Shocks and of Pollicy Responses to External Shocks, in Selected Newly-Industrializing Economies

\section{External Shocks} (percent of GDP)
Policy Responses to External Shocks

\begin{tabular}{|c|c|c|c|}
\hline Additional Net & Export & Import & Deflationary \\
\hline ixternal Financing & Proinotion & Substitution & Policles \\
\hline
\end{tabular}

$1974-1978$

Korea

Taiwan

Argentina

Brazil

Mexico

1978-1981
10.5

7.2

0.5

3.3

1.2

9.4

13.1

1.2

2.5

$-0.5$

-88
-92
-168
30
123

$-18$

$-40$

423

$-33$

309

90
14
-13
15
-70

128

$-30$

82

146

136

66

$-11$

33

14

Brazil

Mexico

Sourcs: World Bank data base. 
Table 6

External Debt Ratios in Selected Newly-Industrializing Economies

External Debt/Exports $\begin{array}{llll}1973 & 1978 \quad 1981 & 1987\end{array}$ $\begin{array}{llll}123 & 100 & 103 & 67\end{array}$

$22 \quad 27 \quad 24 \quad$ na

$\begin{array}{llll}190 & 154 & 249 & 527\end{array}$

$\begin{array}{llll}209 & 368 & 278 & 282\end{array}$

Brazil

Mexico

$\begin{array}{llll}398 & 512 & 271 & 417\end{array}$

Debt Service/Exports $\begin{array}{llll}1973 & 1978 & 1981 & 1987\end{array}$

$\begin{array}{llll}21 & 16 & 19 & 15\end{array}$

$\begin{array}{llll}6 & 7 & 8 & \text { na }\end{array}$

$42 \quad 44 \quad 44 \quad 140$

$\begin{array}{llll}15 & 66 & 66 & 87\end{array}$

$83 \quad 120 \quad 54 \quad 66$

Sources: World Bank data base.

IMF, International Financial Statigtics. 
Table 7

Savings and Investment Ratios in Selected Newly-Industrializing Economies (percentage of GDP)

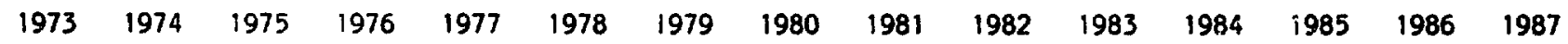

\section{Kor.:}

\begin{tabular}{|c|c|c|c|c|c|c|c|c|c|c|c|c|c|c|c|}
\hline Domestic Savings & 21.6 & 20.6 & 18.5 & 24.1 & 27.5 & 28.5 & 28.2 & 23.3 & 23.7 & 24.9 & 27.6 & 30.5 & 30.5 & 35.0 & 37.0 \\
\hline Foreign Sow' & 2.9 & 10.9 & 8.5 & 1.3 & -0.2 & 3.0 & 7.3 & 7.8 & 5.4 & 2.6 & 1.3 & 0.3 & -0.5 & -5.8 & -8.5 \\
\hline Dorrastic $\because$ - iment & 24.5 & 31.6 & 27.1 & 25.3 & 27.3 & 31.4 & 35.5 & 31.1 & 29.1 & 27.4 & 28.9 & 30,8 & 30.0 & 29.2 & 29.1 \\
\hline
\end{tabular}

\section{Taitan}

Domestic Savings

For:ign Sü

$\begin{array}{llll}34.6 & 31.7 & 27.3 & 33.0\end{array}$

33.33

$\begin{array}{llll}-5.3 & 7.8 & 3.3 & -2.2\end{array}$

$.2-4.9$

Domestic Inisestment

$\begin{array}{llll}29.3 & 39.5 & 30.6 & 30 .\end{array}$

$28.4 \quad-6.5 \quad-1.1$

$\begin{array}{rrrrrrrrr}4.5 & 33.1 & 32.4 & 30.4 & 32.0 & 33.0 & 32.3 & 37.1 & 38.8 \\ 1.1 & 1.2 & -2.1 & -5.3 & -9.0 & -11.6 & -14.5 & -20.8 & -19.2 \\ 3.3 & 34.3 & 30.3 & 25.2 & 23.0 & 21.5 & 17.9 & 16.2 & 19.6\end{array}$

Source: Wor id Bank data base. 
WPS257 Growth, External Debt, and the Real Exchange Rate in Mexico

WPS258 Understanding Voluntary Organizations: Guidelines for Donors

WPS259 Dealing with Debt: The 1930s and the 1980s

WPS260 Growth, Debt, end Sovereign Risk in a Small, Open Economy

WPS261 Inflation, External Debt and Financial Sector Reform: A Quantitative Approach to Consistent Fiscal Policy

WPS262 Adjustment and External Shocks in Ireland

WPS263 How Has Instability in World Markets Affected Agricultural Export Producers in Developing Countries

WPS264 Two Irrigation Systems in Colombia: Their Performance and Transfer of Management to Users' Associations

WPS265 The Influence of Imperfect Competition in International Markets: Some Empirical Evidence

WPS266 Policy Changes that Encourage Private Business Investment in Colombia

WPS267 Issues in Income Tax Reform in Developing Countries

WPS268 Shortcomings in the Market for Developing Country Debt

WPS269 Women in Devnlopment: Issues for Economic and Sector Analysis
Sweder van Wijnbergen

August 1989

M. Bailey 31854

L. David Brown

David C. Korten

Z. Kranzer 69485

Barry Eichingrean

Richard Portes

August 1989

S. King-Watson 33730

Jagdeep S. Bhandari Nadeem UI Haque Stephen J. Turnovsky

August 1989

R. Luz 61588

Sweder van Wijnbergen Roberto Rocha Ritu Anand

August 1989 M. Bailey 31854

Dermot McAleese F. Desmond McCarthy

August 1989 M. Divino 33739

Peter Hazell Mauricio Jaramillo

Amy Williamson

Herve Plusquellec

H. Plusquellec 30348

Alexander Yeats

August 1989

C. Spooner 30464

August 1989

M. Raggambi 61696

Cheryl W. Gray

John Wakeman-Linn

September 1989

S. King-Watson 33730

Women in Development Division
J. Lai 33753 
WPS270 Fuelwood Stumpage: Financing Renewable Energy for the World's Other Half

Charles Feinstein

Katherine Terrell Jan Svejnar

Economic Pertormance in Senegal: A Study of Enterprise Ownership, Export Orientation, and Government Regulation

WPS272 Women's Changing Participation in the Labor Force: A World Perspective

WPS273 FY88 Annual Sector Review: Population, Health and Nutrition

WPS274 The Demography of Zaire: Review of Trends in Mortality and Fertility

WPS275 Revised Estimates and Projections of International Migration, 1980-2000

WPS276 Improving Rural Wages in India

WPS277 The Effect of Formal Credit on Output and Employment in Rural India

WPS278 Inflation and the Company Tax Base Methods to Minimize Inflation-Induced Distortions

WPS279 What Determines the Rate of Growth and Technological Change

WPS280 Adjustment Policies in East Asia

WPS281 Tariff Policy and Taxation in Developing Countries

WPS282 EMENA Manufactured Exports and EEC Trade Policy

WPS283 Experiences of Financial Distress in Thailand
Population and Human

Resources Department

Miriam Schneidman

Fred Arnold

Shahidur R. Khandker

Shahidur R. Khandker Hans P. Binswanger

Anand Rajaram

September 1989

A. Bhalla 60359

Paul M. Romer

Bela Balassa

Bela Balassa

Bela Balassa

Tipsuda Sundaravej Prasarn Trairatvorakul
September 1989 N. Campbell 33769

September 1989 N. Campbell 33769

September $1989 \quad$ N. Campbell 33769 